\title{
Examining Linkages between Saudi Stock Market (TASI) and Selected Stock Markets Indices
}

\author{
Mohammed Ziaur Rehman ${ }^{1} \&$ Musa Ahmed Hazazi ${ }^{2}$ \\ ${ }^{1}$ Department of Finance, College of Business Administration, King Saud University, Riyadh, Kingdom of Saudi \\ Arabia \\ ${ }^{2}$ MSF Programe, Department of Finance, College of Business Administration, King Saud University, Riyadh, \\ Kingdom of Saudi Arabia \\ Correspondence: Mohammed Ziaur Rehman, Assistant Professor, Department of Finance, College of Business \\ Administration, King Saud University, Riyadh, Kingdom of Saudi Arabia. E-mail: ziacommerce@gmail.com
}

Received: September 25, 2014

Accepted: October 15, $2014 \quad$ Online Published: October 17, 2014

doi:10.5430/ijfr.v5n4p196

URL: http://dx.doi.org/10.5430/ijfr.v5n4p196

\begin{abstract}
This study makes an endeavor to examine the existence of linkages between Saudi Stock Market Index (TASI) and the bigwig stock markets indices, namely, US, UK, Japan and Gulf Cooperation Council (GCC). Data are culled and collated on a weekly basis commencing from 01/07/2004 to 31/12/2008 for the Period-I (This phase cover substantial economic boom period in Saudi Arabia) and from 01/01/2009 to 31/07/2013 for the Period-II (This duration encapsulates major restructuring in the Saudi stock market sectors). Significant tests are employed in the study, namely, the Pearson Correlation, Unit root, Johansen Co-integration, and Pairwise Causality tests. The results have demonstrated that volatility of TASI returns have decreased over the years and the correlations between the stock markets have increased. Further, the study reveals that the stock market indices have integration traits. Similarly, numerous causations between stock markets indices have increased in the period-II. Therefore, these findings are pertinent for all investors at domestic and international level. Further the findings of the study shall sanguinely carve a niche on the literature domain of Saudi Stock Market Index (TASI).
\end{abstract}

Keywords: TASI, CMA, MENA, GCC, market linkages, stock market

\section{Introduction}

Over the past few decades, the concept of linkage among equity markets around the world has gained wide currency. As portfolio theory postulate that gains from diversification sans risk depends on low correlation among securities, it is pertinent to gauge the securities markets dependence to fortify the portfolio performance by locating less correlated markets. Escalated international trade, technological innovations and financial market liberalization are the cardinal ingredients in accelerating the pace of investment inflows and outflows at international echelon of business and thereby providing fillip to syncing of national equity markets. This association among economies contributes to rising homogeneity in market performance in reactions to international financial effects. The integration of financial markets hinges on dexterity of international investors to drive in the other market securities. Further the process of integration gets propelled by the expectations and information outlook of investors in employing fund in overseas stock investment. Accordingly, the dynamics of integration among the equity markets bring to fore the attention of erudite investors and academic pundits on the multifarious facets of international investment decisions and policy implications.

Global reports cogently corroborate Saudi Arabia as the largest economy in the Middle East and North Africa (MENA) region and the $13^{\text {th }}$ most economically competitive country in the world. Further the Kingdom is member of G20, OPEC and of the WTO. The Kingdom is ranked eighth among the world's ten high growth economies by the International Monetary Fund (IMF). TASI is recognized as one of the top equity market in the Middle East region. Reports provide evidence that the Saudi capital market has been second to none in the Arab capital markets during the last ten years. Of late, Saudi market has led the Middle East region in Initial Public Offering (IPOs) too. The landscape of Saudi Capital Market has witnessed transformation from being ordinary regulatory and legal structure in 1970s to increased disclosure and transparency regime in 2010 onwards. The saga of international investment inflow in the kingdom started on account of accelerated economic reforms during the 1990s that unfolded the pace of privatization and liberalization on the Saudi capital market. Further, in 2001, the commencement of Tadawul accelerated the trading volume in Saudi stocks and correspondingly led to establishment of new official Saudi Stock 
Market Index christened as TASI (Tadawul All Share Index). From 2003 onward, an all integrated endeavor has been formed to enhance the regulatory capability of Capital Market Authority (CMA); the regulator of Saudi stock market in order to enhance the level of transparency in the market.

In this vein, Tadawul was established into a Joint Stock Company in 2007 to draw in international best practices. The CMA, at regular interval, unveils a set of measures to unfold the Saudi Stock Market for additional foreign participation. Further, introduction of corporate governance guidelines are aimed at increasing transparency and investors' confidence. The extant statistic reports that the Saudi stock market encompasses 164 companies spread across 15 different sectors. The Petrochemical and the Banks \& Financial Services sectors encapsulate more 50 percent of the total market capitalization. With the significant growth and development of Saudi Stock Market; it is quite pertinent to investigate the level of integration of TASI with other stock markets at the international sphere. The motivation for presenting Saudi stock market is on account of being regarded as a promising location for investment opportunities. Thus it is topical to explore the interdependence of Saudi Stock Market with international markets in order to appreciate the portfolio diversification opportunities for individual and institutional investors. The present study makes an endeavor to investigate the association of TASI with select stock markets. The remainder of this paper is structured as: Section II exhibits an extant literature related with the study. Section III encompasses the research methodology adopted for the study. Section IV provides thorough analysis of the results. Lastly, Section V presents the epilogue of the study.

\section{Extant Literature}

An increased attention on linkage of stock markets at the international level is manifested by the numerous works through investigating multifarious facets of stock markets interconnection. The driving forces for the increased pace of umpteen studies on integration of stock markets are the occurrences of stock market crash in 1987, Asian Financial Crisis in 1997 and US financial crisis in 2006. One set of studies reveal the evidence of correlation in developed stock markets (Kasa, 1992; Richards, 1995; Hamori and Imamura, 2000; Ahlgren and Antell, 2002). In the same vein, studies demonstrate linkage among the equity stock markets and have revealed the potent of US as being the most influential market (Eun and Shim, 1989; Cheung and Mak,1992; Park and Fatemi,1993; Choudhury,1994; Gerrits and Yuce, 1999; Masih and Masih,1999).

Studies reveal that motivation of earnings from international markets emerges on account of lower correlation between domestic assets and international markets (Grubel, 1968; Levy\&Sarnat, 1970). However, it is cogently reported that the anticipated benefits from international diversification has been trimmed down on account of strengthening of co-movement among international equity markets (Eun and Shim,1989; Taylor and Tonks, 1989). Thus the investors have started seeking greener pastures on the landscape of emerging markets. The global investors aim at emerging market in anticipation that correlation between developed markets and emerging markets will be unrelated. Studies corroborate that there is a substantial shift in investment from developed markets to emerging markets on account of superior diversification possibility (Bekaert and Harvey, 1995; Driessen and Laeven, 2007; Chang, Chen, and Lee, 2008; Gupta and Donleavy, 2009). Another set of studies state that correlations between international equity markets are time variant (Karolyi and Stultz, 1996; Lee and Kim,1993; Forbes and Rigobon,2002; Siddiqui,2009). Selected studies reveal lack of relationship among stock markets (Bodla and Turan, 2006; Hoque 2007; Rajiv Menon et al. ,2009).

An endeavor is made to review select studies concentrating on the integration level of Middle East and North Africa (MENA) and of Gulf Cooperation Council (GCC) stock markets. Parsva and Lean (2011) manifest that MENA markets and exchange rates were cointegrated during the current global financial crisis. (Neaime, 2005) recommends that financial integration in the MENA region shall reduce the cost of capital and will further spell out in increased investment, consumption and superior GDP rates in the region. (Maghyereh, 2007) reveals high level of long-range dependence in equity returns and volatility in the MENA stock markets. The study's outcome is in line with results from other leading regional markets. Multiples studies unfold the partitioning of Middle East and North Africa (MENA) stock markets from global premier financial markets and thereby proffering diversification opportunities for global investors. (Cheng et al., 2010) investigates excess market returns in nine MENA countries and manifest that the markets returns for the stated markets are anticipated to have unrelated returns with the global returns, thereby can provide portfolio diversification. (Lagoarde-Segot \& Lucey, 2007) reports on capital market integration in Middle Eastern and North African (MENA) countries and its significance on the sphere of international portfolio investment. The study documents the evidence of substantial diversification opportunities for investors. (Girard \& Ferreira, 2004) explore the role of MENA stock markets to the global asset allocation plan. The study reports the stipulated market offer diversification opportunities for the global investors.(Graham, Kiviaho, Nikkinen, \& Omran, 2013) uncover the co-movement of selected MENA region stock markets with the U.S. stock market. The study confirms the presence of short term diversification gains. 
(Bley, 2007) explores the effect of multiple stock market movements on the MENA stock markets. The study manifests that MENA region holds diversification benefits and recommends the incorporation of MENA equity in an international portfolio.(Paskelian, Nguyen, \& Jones, 2013) investigates the attributes of stock markets equity indices of various MENA countries. The study manifests substantial bidirectional causalities in the regional stock markets but is not extremely related with the US market. Nevertheless, the imperfection in the region prohibits the investors to garner the diversification benefits. (Olusi \& Abdul-Majid, 2008) explores the range to which Eurozone and MENA equity markets are related. As a result, the study reveals the opportunity of diversification gains in MENA equity markets. Selected studies failed to identify significant cross linkages (Darrat, Elkhal, and Hakim 2000; Omran and Gunduz 2001). (Dania \& Udemgba, 2011) explores the integration of MENA equity markets with the global developed markets of France, Germany, UK and the US. The study documents the interdependence between MENA stock markets and the stated developed markets. Neaime (2012) investigates the market linkage between MENA and developed markets and on inter regional basis among the MENA stock markets. The study reports evidence of association among the MENA stock markets.

(Assaf, 2003) explores the interactions among stock market returns from six (GCC) countries and reports the substantial steps taken to strengthened financial integration in the GCC arena. The study documents interdependence among GCC stock markets. (Arouri \& Nguyen, 2009) endeavor to study the time variant attribute of cross-market correlations in select Gulf stock markets. The study reveals that the conditional cross-market correlations between studied markets is time variant and the co-movements between the Gulf stock markets and the world market is insignificant. In this vein, the study advocates the investors, the opportunities for diversification in Gulf markets.(Al-Khazali, Darrat, \& Saad, 2006) report the existence of link in the four equity markets of Saudi Arabia, Kuwait, Bahrain and Oman. Further, the purported Gulf markets manifest a booming long-run relationship. Thus, the study manifests that as the level of integration shall increase, gains from the portfolio diversification shall wane. (Alkulaib, Najand, \& Mashayekh, 2009) uncover that the streamlining of security regulations in MENA proffers substantial opportunities for foreign investors. The study documents more interplay in GCC arena than in North Africa and Levant sphere.(Bley, 2011) states the enhanced association of foreign institutional investors may act as an important instrument in increasing the serial correlation. (Yu \& Hassan, 2008) explore the financial integration of MENA arena to lighten a detail study of interdependence framework between MENA and international stock markets. The volatility spillover from the internal landscape exceeded the cross volatility in the study. (Espinoza, Prasad, \& Williams, 2011) explore the level of financial integration in gulf region. The study reports considerable integration in the gulf markets in comparison to other emerging markets. (Balli, Basher, \& Jean Louis, 2013) document the better performance of portfolio diversification in GCC wide sector than in GCC national equity markets. The study reports that the role of regional shocks is more than global shocks in explaining the volatility of GCC sector returns.

Laconically, the extant literature review presents variant results on account of sample period chosen, selection of markets, frequency of observations and different methodologies adopted to gauge the interrelationship of equity markets. The current study aims to provide fillip to current literature review on the purported topic.

\section{Research Methodology}

This paper aims to provide comprehensive evidence on the relationship between Saudi stock market (TASI) and selected stock markets indices. The study concentrates on secondary data, which envelop the closing figures of stock indices of selected international stock markets. The Saudi stock market is closed on Fridays and Saturdays, while other worldwide stock markets are closed on Saturdays and Sundays. To settle this matter, weekly data is used in the study. Tuesdays are used as weekdays for all the variables in this study as the latter lies in the middle of the three common trading days for all markets. For appreciation and to investigate time variant aspect, the time period is classified into two equal parts. The first period from 2003 to 2008 was the substantial economic boom period in Saudi Arabia. The second Period from 2009 to 2013 covers major restructuring in the Saudi stock market sectors based on the nature of business by classifying new sectors(from 8 to 15 sectors). Accordingly, Period-I starts from 01/07/2004 to 31/12/2008 and Period-II is set out between 01/01/2009 to 31/07/2013. The data used in this study are weekly observations from Yahoo Finance, Saudi Stock Exchange (Tadawul), and Bloomberg.

\section{Rationale for the selecting Stock Markets Indices:}

The following section gives a summary of chosen indices:

- TASI: The Tadawul All Share Index (TASI) is the stock market index which manifests the performance of all companies listed on the Saudi Stock Exchange.

- GCC Indices: Since these countries are part of the Middle East Gulf region and partake in economic, political and cultural ties, it is central to encompass the related stock markets. 
I. Dubai Financial Market (DFMGI).

II. Abu Dhabi Securities Market (ADSMI).

III. Kuwait Stock Exchange (SECTMIND).

IV. Bahrain Bourse All Share Index (BHSEASI).

V. Qatar Exchange Index, Doha (DSM).

VI. Muscat Securities Index (MSM30).

- Japanese Index: Saudi Arabia is the second largest export market for Japanese goods in the Gulf region and the first in terms of exports from the Gulf to Japan, therefore the index of Japan is selected. The most commonly used indices in Japan are TOPIX and Nikkei 225. Nikkei225 is selected on account of high frequency.

- US Indices: Saudi Arabia is America's leading trading partner in the world. The most commonly used indices in US are DJIA, S\&P 500 and NASDAQ Composite. Accordingly, the stated indices are taken for study.

- The UK Index: Saudi Arabia is the UK's largest market for goods and services outside the OECD and the principal trade and investment ally in the Middle East region. Among all the indices within the LSE, the FTSE 100 is widely used stock indices and is acknowledged as a measure of business prosperity.

Table 1. Selected stock markets indices

\begin{tabular}{cccc}
\hline & Country & Index & Symbol \\
\hline 1 & Saudi Arabia & Tadawul All Share (TASI) & SASEIDX \\
\hline 2 & UAE, Dubai, GCC & Dubai Financial Market & DFMGI \\
\hline 3 & UAE, Abu Dhabi, GCC & Abu Dhabi Securities Market & ADSMI \\
\hline 4 & Kuwait, GCC & Kuwait Stock Exchange & SECTMIND \\
\hline 5 & Oman, GCC & Muscat Securities MSM 30 & MSM30 \\
\hline 6 & Bahrain, GCC & Bahrain Bourse All Share Index & BHSEASI \\
\hline 7 & Qatar, GCC & Qatar Exchange Index, Doha & DSM \\
\hline 8 & US & Dow Jones Industrial Average (DJA) & DJI \\
\hline 9 & US & S\&P 500 & GSPC \\
\hline 10 & US & NASDAQ Composite & FXIC \\
\hline 11 & UK & FTSE & N225 \\
\hline 12 & Japan & Nikkei 225 &
\end{tabular}

Hypotheses: There are five hypotheses formulated for the study as:

H01: The distribution of TASI returns is not normal in the time periods (I\&II).

H02: The period wise correlation of TASI with the selected stock markets indices is unchanged.

H03: Existence of Unit Root (non-stationary) in TASI and the selected stock markets indices in the time period (I\&II).

H04: Co-integration remains unchanged between TASI and the selected stock markets indices in Period-II.

H05: Granger Causality remains unchanged between TASI and the selected stock markets indices in Period-II.

In this study, following statistical and econometric tools are undertaken:

- To ascertain whether returns of stock markets follow the normal probability distribution, the Jarque-Bera test is employed.

- Pearson correlation test is applied to ascertain the correlation between the stock markets returns.

- To check the stationary nature of the series, Unit root test is applied by employing the Augmented Dickey-Fuller (ADF) test.

- To estimate the long run relationship among the indices under study, Co-integration test is employed. 
- To investigate the direction of the influence from one series to another, the Granger Causality test is applied.

In the study, weekly returns of the indices are employed by using the natural logarithm of the weekly closing price as the following: $\mathbf{R}=\ln (\mathbf{P t} / \mathbf{P t}-1)$.

\section{Analysis of the Results}

The descriptive statistics of the stock indices are presented in Table 2A (for Period-I) and Table 2B (for Period-II). Both the tables cover the summary statistics, namely sample means, minimums, maximums, medians, standard deviations (SD), skewness and kurtosis. SECTMIND and MSM30 have registered the highest mean during the period-I, while IXIC and GSPC have registered the highest mean during the period-II. It is revealed that DFMGI witnessed the highest standard deviation during both the stipulated Period (I\&II). Whereas, BHSEASI has the lowest standard deviation and thereby manifests least volatility during periods (I\&II). Moreover, it is noted that only FTSE reveals positive skewness during the period-I. In the period-II, the standard deviations of eight indices have reduced, thereby revealing the decline in volatility.

Table 2A. Descriptive statistics of stock indices (Period-I)

\begin{tabular}{ccccccccccccccc}
\hline & TASI & ADSMI & BHSEASI & DFMGI & DJI & DSM & FTSE & GSPC & IXIC & MSM30 & N225 & SECTMIND \\
\hline Mean & -0.0008 & 0.0004 & 0.0008 & 0.0002 & -0.0007 & 0.0013 & 0.0000 & -0.0010 & -0.0010 & 0.0019 & -0.0011 & 0.0019 \\
\hline Median & 0.0102 & 0.0003 & 0.0002 & 0.0004 & 0.0023 & 0.0000 & 0.0022 & 0.0016 & 0.0022 & 0.0019 & 0.0033 & 0.0052 \\
\hline Maximum & 0.1371 & 0.1667 & 0.0605 & 0.1551 & 0.0600 & 0.1437 & 0.1658 & 0.0671 & 0.0762 & 0.0993 & 0.1788 & 0.0852 \\
\hline Minimum & -0.2322 & -0.1530 & -0.0912 & -0.2186 & -0.1385 & -0.2405 & -0.0838 & -0.1577 & -0.1757 & -0.2106 & -0.1997 & -0.1408 \\
\hline Std. Dev. & 0.0520 & 0.0410 & 0.0176 & 0.0545 & 0.0208 & 0.0478 & 0.0235 & 0.0223 & 0.0264 & 0.0339 & 0.0339 & 0.0296 \\
\hline Skewness & -1.2713 & -0.2252 & -0.3923 & -0.7001 & -1.7659 & -0.8209 & 0.7344 & -2.0850 & -1.7253 & -1.8195 & -0.6819 & -1.1002 \\
\hline Kurtosis & 6.1731 & 5.8060 & 6.9942 & 5.9563 & 12.6591 & 7.2060 & 13.9011 & 15.1039 & 11.9720 & 12.6452 & 10.7044 & 6.5169 \\
\hline Obs & 235 & 235 & 235 & 235 & 235 & 235 & 235 & 235 & 235 & 235 & 235 & 235 \\
\hline
\end{tabular}

Table 2B. Descriptive statistics of stock indices (Period-II)

\begin{tabular}{ccccccccccccccc}
\hline & TASI & ADSMI & BHSEASI & DFMGI & DJI & DSM & FTSE & GSPC & IXIC & MSM30 & N225 & SECTMIND \\
\hline Mean & 0.0017 & 0.0018 & -0.0017 & 0.0016 & 0.0023 & 0.0017 & 0.0017 & 0.0025 & 0.0033 & 0.0009 & 0.0018 & 0.0007 \\
\hline Median & 0.0029 & 0.0000 & -0.0011 & 0.0019 & 0.0037 & 0.0022 & 0.0036 & 0.0059 & 0.0080 & 0.0021 & 0.0023 & 0.0022 \\
\hline Maximum & 0.0922 & 0.0958 & 0.0262 & 0.1247 & 0.0655 & 0.1084 & 0.0844 & 0.0782 & 0.0737 & 0.1395 & 0.1193 & 0.0880 \\
\hline Minimum & -0.1296 & -0.1175 & -0.0552 & -0.1505 & -0.0888 & -0.2167 & -0.1022 & -0.1046 & -0.0875 & -0.1603 & -0.2014 & -0.1185 \\
\hline Std. Dev. & 0.0280 & 0.0228 & 0.0129 & 0.0359 & 0.0225 & 0.0320 & 0.0258 & 0.0251 & 0.0268 & 0.0231 & 0.0336 & 0.0228 \\
\hline Skewness & -0.9893 & -0.4680 & -0.8749 & -0.5541 & -0.4896 & -1.3974 & -0.5466 & -0.6296 & -0.4438 & -0.8186 & -0.6874 & -0.7572 \\
\hline Kurtosis & 7.7316 & 8.4736 & 5.0161 & 5.6388 & 4.4986 & 14.0789 & 4.4938 & 4.7841 & 3.6665 & 18.8388 & 8.7999 & 8.6003 \\
\hline Obs & 239 & 239 & 239 & 239 & 239 & 239 & 239 & 239 & 239 & 239 & 239 & 239 \\
\hline
\end{tabular}

Jarque-Bera test statistics are applied on the stock indices returns to investigate the normal distribution of the series. Tables 3(A\&B) pertain to Jarque Bera test for the stock indices returns for the period (I\&II). Under the null hypotheses of normality, the output of the results reveals that the P-values of the Jarque Bera are less than 5\% which reveals that the stock indices returns are not normally distributed during the stipulated period. Thus the first hypothesis is accepted and direct towards the matter of stationary of the purported returns series.

Table 3A. Jarque Bera Test for the stock indices returns (Period-I)

\begin{tabular}{cccccccccccccc}
\hline & TASI & ADSMI & BHSEASI & DFMGI & DJI & DSM & FTSE & GSPC & IXIC & MSM30 & N225 & SECTMIND \\
\hline Jarque-Bera & 161.89 & 79.08 & 162.24 & 104.78 & 1035.67 & 199.61 & 1184.71 & 1604.80 & 904.79 & 1040.59 & 599.42 & 168.52 \\
\hline Probability & 0 & 0 & 0 & 0 & 0 & 0 & 0 & 0 & 0 & 0 & 0 & 0 \\
\hline
\end{tabular}


Table 3B. Jarque-Bera Test for the stock indices returns (Period-II)

\begin{tabular}{cccccccccccccc}
\hline & TASI & ADSMI & BHSEASI & DFMGI & DJI & DSM & FTSE & GSPC & IXIC & MSM30 & N225 & SECTMIND \\
\hline Jarque-Bera & 261.94 & 307.08 & 70.96 & 81.57 & 31.91 & 1300.08 & 34.12 & 47.49 & 12.27 & 2524.93 & 353.81 & 335.16 \\
\hline Probability & 0 & 0 & 0 & 0 & 0 & 0 & 0 & 0 & 0 & 0 & 0 & 0 \\
\hline
\end{tabular}

Tables 4(A\&B) show the return correlations among the selected indices. In general, the correlation coefficient can have values from -1 to +1 . The existences of correlations among the purported stock indices reveal the integration level of their financial landscape. During the first period, it is cogently reported that TASI has highest positive correlation with ADSMI and DFMGI with a value (.56). The highest correlation in the table $4 \mathrm{~A}$ is revealed by GSPC with DJI \& IXIC having the highest value of (.97) and (.94). During the period-II, it is revealed that out of eleven indices, the correlation of TASI with seven indices has increased. Repeatedly, the highest correlation in the table is revealed by GSPC with DJI \& IXIC having the highest value of (.98) and (.96).

Table 4A. Correlations of returns of the stock indices (Period-I)

\begin{tabular}{|c|c|c|c|c|c|c|c|c|c|c|c|c|}
\hline & TASI & ADSMI & BHSEASI & DFMGI & DJI & DSM & FTSE & GSPC & IXIC & MSM30 & $\mathrm{N} 225$ & SECTMIND \\
\hline TASI & 1 & & & & & & & & & & & \\
\hline ADSMI & 0.56 & 1 & & & & & & & & & & \\
\hline BHSEASI & 0.33 & 0.43 & 1 & & & & & & & & & \\
\hline DFMGI & 0.56 & 0.79 & 0.42 & 1 & & & & & & & & \\
\hline FTSE & 0.24 & 0.20 & 0.30 & 0.24 & 0.68 & 0.38 & 1 & & & & & \\
\hline GSPC & 0.26 & 0.25 & 0.27 & 0.32 & 0.97 & 0.29 & 0.71 & 1 & & & & \\
\hline IXIC & 0.24 & 0.21 & 0.28 & 0.29 & 0.88 & 0.26 & 0.67 & 0.94 & 1 & & & \\
\hline
\end{tabular}

Table 4B. Correlations of returns of the stock indices (Period-II)

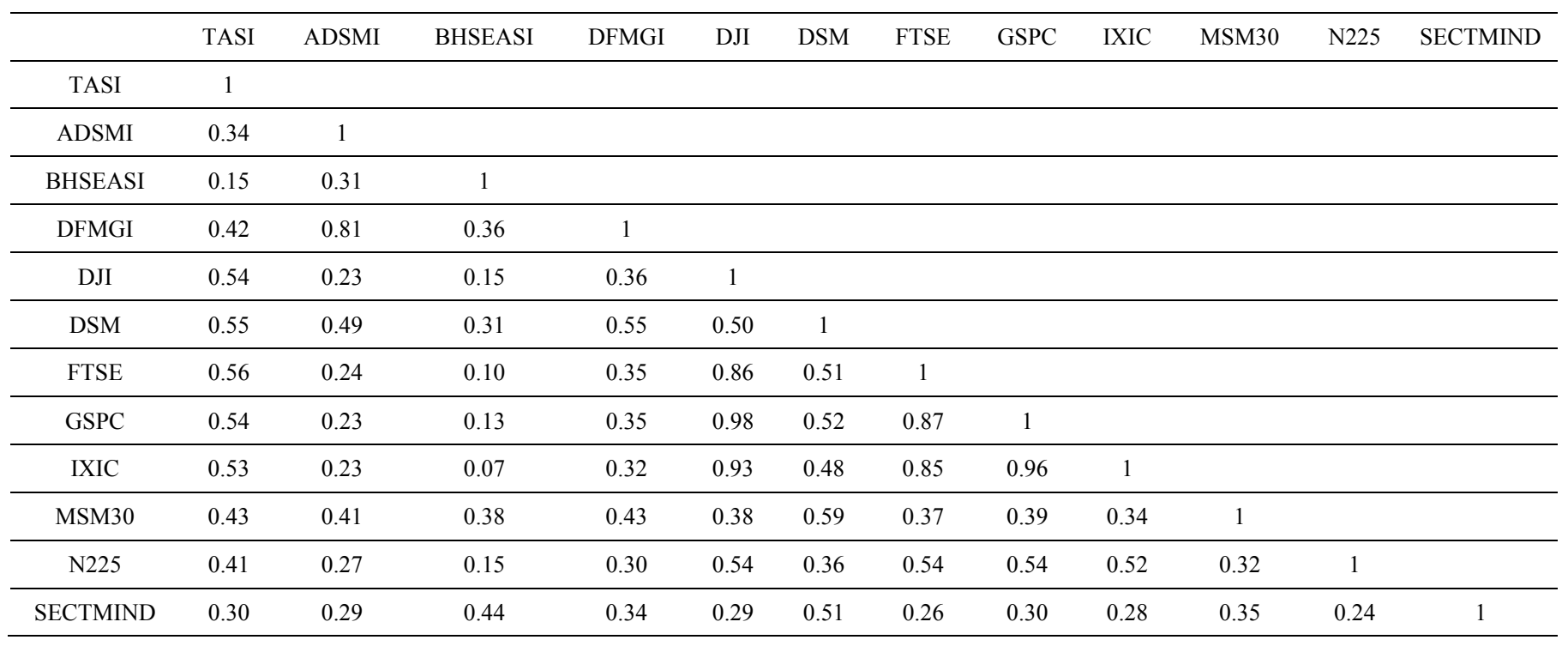


From the Table 4B, it is revealed that correlation among the indices returns have increased in 41 out of 66 possible correlations, which provide clear manifestation for the increased interdependency among the purported indices. Thus the second hypothesis is rejected. During period-II, TASI, DFMGI and DJI have revealed the maximum numbers of increased changed. Tables 4 (A\&B) revealed the correlation among the stock indices, but more valuable statistical tools are required to gauge the relationship among the indices. Thus Co-integration test and Granger causality test are applied to appreciate the connection among the indices. Augmented Dickey-Fuller (ADF) test is applied to test the returns series for stationarity. The existence of a unit root is taken as the null hypothesis. From the tables 5 (A\&B), it is revealed that the test equation at the level $(1 \%, 5 \%, 10 \%)$ and the first differences for both the period rejects the null hypotheses because the P-values are less than $5 \%$ as well as the absolute $\mathrm{t}$ statistics are more than the test critical values at that level which reports that all the series are stationary. Thus the third hypothesis is rejected.

Table 5A. (ADF, UR Test) Period-I Summary

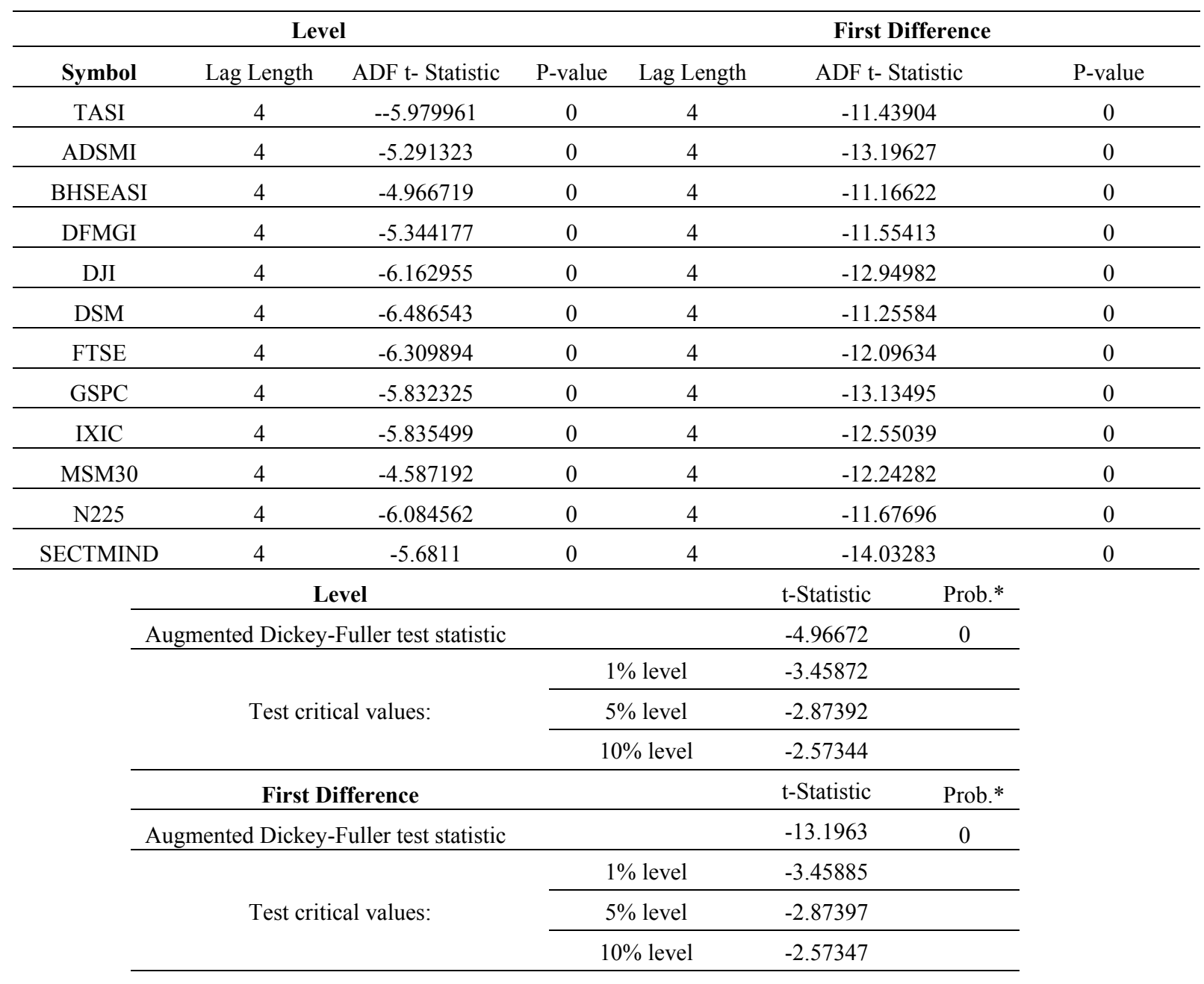


Table 5B. (ADF, UR Test) Period-II Summary

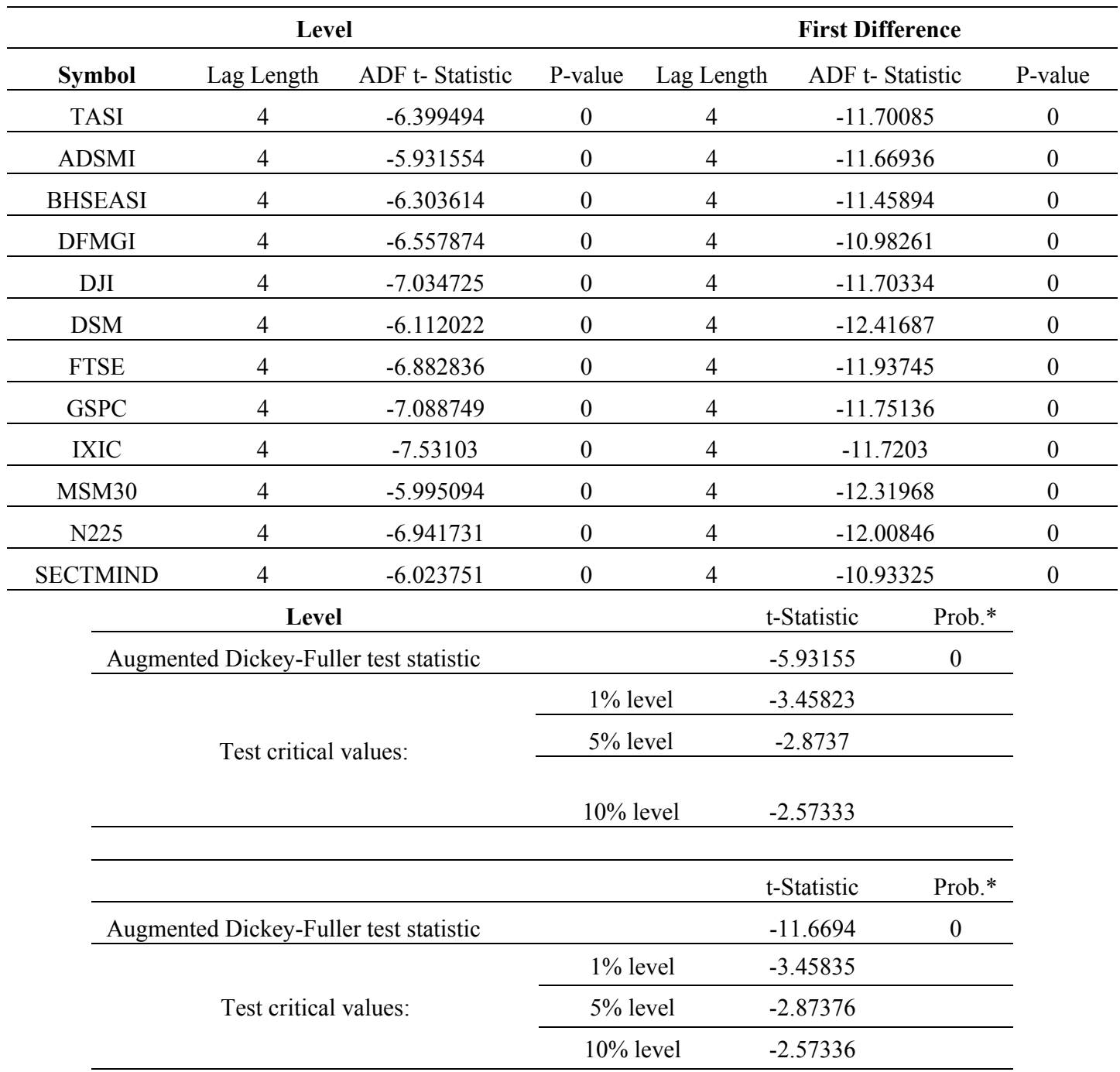

*MacKinnon (1996) one-sided p-values

The utility of cointegration test is to ascertain the existence of any co-integrating relationship among the selected stock indices returns. When the selected variables having stochastic trends move together in such a fashion that reveals a common trends, it exhibit co-integration relationship. The output of the unit root test reveals that the time series of selected stock indices are stationary. Co-integration presents a unique form of long-run relationship among the selected stock indices. Thus cointegration provides the support for the pairs trading strategy. Tables 6 (A\&B) show whether the indices under study have long run relationships. Thus co-integration shall be a suited tool for testing hypotheses related to the long-term relationship among the selected stock indices returns. From both periods (I\&II), it is exhibited that statistic values are significantly greater than critical values besides P-values are less than $5 \%$. Moreover, the Maximum Eigen Value Test reveals that the equation have strengthen to twelve from eleven in period-I which indicates improved cointegration in Period-II. Thus the fourth hypothesis is rejected. It can therefore be reported that the co-integration reveals merely co-movements between two time series over a period of time among the selected variables. In sum, the bigwigs stock indices move across the international echelon in unison. 


\section{Johansen Co-integration Test}

Table 6A. Co-integration Tests (Period-I)

Sample (adjusted): 6235

Included observations: 230 after adjustments

Trend assumption: Linear deterministic trend

Series: TASI ADSMI BHSEASI DFMGI DJI DSM FTSE GSPC IXIC MSM30 N225 SECTMIND

Lags interval (in first differences): 1 to 4

\section{Unrestricted Cointegration Rank Test (Trace)}

\begin{tabular}{ccccc}
\hline Hypothesized & & Trace & 0.05 & \\
\hline No. of CE(s) & Eigenvalue & Statistic & Critical Value & Prob.** \\
\hline None * & 0.350746 & 598.794 & 334.9837 & 0 \\
\hline At most 1 & 0.315948 & 499.449 & 285.1425 & 0 \\
\hline At most 2* & 0.271946 & 412.114 & 239.2354 & 0 \\
\hline At most 3* & 0.240179 & 339.116 & 197.3709 & 0 \\
\hline At most 4* & 0.230198 & 275.942 & 159.5297 & 0 \\
\hline At most 5* & 0.181056 & 215.769 & 125.6154 & 0 \\
\hline At most 6* & 0.168683 & 169.828 & 95.75366 & 0 \\
\hline At most 7* & 0.155457 & 127.337 & 69.81889 & 0 \\
\hline At most 8* & 0.129873 & 88.4765 & 47.85613 & 0 \\
\hline At most 9* & 0.105747 & 56.4797 & 29.79707 & 0 \\
\hline At most 10* & 0.08313 & 30.7733 & 15.49471 & 0.0001 \\
\hline At most 11 * & 0.045919 & 10.8116 & 3.841466 & 0.001 \\
\hline
\end{tabular}

Trace test indicates 12 cointegrating eqn(s) at the 0.05 level

* denotes rejection of the hypothesis at the 0.05 level

**MacKinnon-Haug-Michelis (1999) p-values

\section{Unrestricted Cointegration Rank Test (Maximum Eigenvalue)}

\begin{tabular}{ccccc}
\hline Hypothesized & & Max-Eigen & 0.05 & \\
\hline No. of CE(s) & Eigenvalue & Statistic & Critical Value & Prob.** \\
\hline None * & 0.350746 & 99.3442 & 76.57843 & 0.0002 \\
\hline At most 1 & 0.315948 & 87.3358 & 70.53513 & 0.0007 \\
\hline At most 2* & 0.271946 & 72.9974 & 64.50472 & 0.0064 \\
\hline At most 3* & 0.240179 & 63.1747 & 58.43354 & 0.016 \\
\hline At most 4* & 0.230198 & 60.1731 & 52.36261 & 0.0066 \\
\hline At most 5 & 0.181056 & 45.9402 & 46.23142 & 0.0537 \\
\hline At most 6* & 0.168683 & 42.4912 & 40.07757 & 0.0262 \\
\hline At most 7* & 0.155457 & 38.8607 & 33.87687 & 0.0117 \\
\hline At most 8* & 0.129873 & 31.9968 & 27.58434 & 0.0127 \\
\hline At most 9* & 0.105747 & 25.7064 & 21.13162 & 0.0106 \\
\hline At most 10* & 0.08313 & 19.9617 & 14.2646 & 0.0056 \\
\hline At most 11 * & 0.045919 & 10.8116 & 3.841466 & 0.001 \\
\hline
\end{tabular}

Max-eigenvalue test indicates 11 cointegrating eqn(s) at the 0.05 level

* denotes rejection of the hypothesis at the 0.05 level

**MacKinnon-Haug-Michelis (1999) p-values 
Table 6B. Co-integration Tests (Period-II)

Sample (adjusted): 6239

Included observations: 234 after adjustments

Trend assumption: Linear deterministic trend

Series: TASI ADSMI BHSEASI DFMGI DJI DSM FTSE GSPC IXIC MSM30 N225 SECTMIND

Lags interval (in first differences): 1 to 4

I. Unrestricted Cointegration Rank Test (Trace)

\begin{tabular}{ccccc}
\hline \multicolumn{2}{c}{ Hypothesized } & Trace & 0.05 & \\
\hline No. of CE(s) & Eigenvalue & Statistic & Critical Value & Prob. $^{* *}$ \\
\hline None & 0.376132 & 711.5719 & 334.9837 & 0 \\
\hline At most $1 *$ & 0.347638 & 601.1667 & 285.1425 & 0 \\
\hline At most $2 *$ & 0.285951 & 501.2121 & 239.2354 & 0 \\
\hline At most $3 *$ & 0.263155 & 422.4 & 197.3709 & 0 \\
\hline At most $4 *$ & 0.247165 & 350.9416 & 159.5297 & 0 \\
\hline At most 5 & 0.23069 & 284.5069 & 125.6154 & 0 \\
\hline At most $6 *$ & 0.214243 & 223.1376 & 95.75366 & 0 \\
\hline At most $7 *$ & 0.183519 & 166.7184 & 69.81889 & 0 \\
\hline At most $8 *$ & 0.141943 & 119.2746 & 47.85613 & 0 \\
\hline At most $9 *$ & 0.128288 & 83.45265 & 29.79707 & 0 \\
\hline At most 10 & 0.126341 & 51.3253 & 15.49471 & 0 \\
\hline At most 11 * & 0.08082 & 19.72008 & 3.841466 & 0 \\
\hline
\end{tabular}

Trace test indicates 12 cointegrating eqn(s) at the 0.05 level

* denotes rejection of the hypothesis at the 0.05 level

**MacKinnon-Haug-Michelis (1999) p-values

II. Unrestricted Cointegration Rank Test (Maximum Eigenvalue)

\begin{tabular}{ccccc}
\hline \multicolumn{2}{c}{ Hypothesized } & Max-Eigen & 0.05 & \\
\hline No. of CE(s) & Eigenvalue & Statistic & Critical Value & Prob. ${ }^{*}$ \\
\hline None ${ }^{*}$ & & & & \\
\hline At most $1 *$ & 0.376132 & 110.4052 & 76.57843 & 0 \\
\hline At most $2 *$ & 0.347638 & 99.95458 & 70.53513 & 0 \\
\hline At most $3 *$ & 0.285951 & 78.81213 & 64.50472 & 0.0013 \\
\hline At most $4 *$ & 0.263155 & 71.45834 & 58.43354 & 0.0017 \\
\hline At most $5 *$ & 0.247165 & 66.43477 & 52.36261 & 0.0011 \\
\hline At most $6 *$ & 0.23069 & 61.36922 & 46.23142 & 0.0007 \\
\hline At most $7 *$ & 0.214243 & 56.41927 & 40.07757 & 0.0003 \\
\hline At most $8 *$ & 0.183519 & 47.44381 & 33.87687 & 0.0007 \\
\hline At most $9 *$ & 0.141943 & 35.82193 & 27.58434 & 0.0035 \\
\hline At most $10 *$ & 0.128288 & 32.12735 & 21.13162 & 0.001 \\
\hline At most $11 *$ & 0.126341 & 31.60522 & 14.2646 & 0 \\
\hline
\end{tabular}

Max-eigenvalue test indicates 12 cointegrating eqn(s) at the 0.05 level

* denotes rejection of the hypothesis at the 0.05 level

**MacKinnon-Haug-Michelis (1999) p-values 
After testing for stationary using the ADF unit root test, succeeded by the Johansen co-integration test, it is central to perform the Granger causality test. The Granger causality test is a tool for investigating whether one variable is central in predicting another variable. A variable $\mathrm{X}$ is referred to 'Granger cause' variable $\mathrm{Y}$, if the previous values of X could forecast the current value of Y. Granger causality test explores whether a substantial influence exists between stock markets indices. The study endeavors to unearth whether there is change in Granger Causality between TASI and other indices in the Period-II. The test reveals that all the variables are stationary and the likely outcomes of the observations are as following:

- Unidirectional Granger causality from variable $X$ to $Y$.

- Unidirectional Granger causality from variable $\mathrm{Y}$ to $\mathrm{X}$.

- Bi-directional causality.

- No causality.

From both Tables 7(A\&B), noticeable changes are witnessed, the number of one way causations (unidirectional causality) have risen twice from the period-I to the period-II (from 21 to 40 causations). On the contrary, bidirectional causations have decreased tremendously in the period-II (from 50 to 8 causations). Further there are multiple observations reported from both the periods. It is revealed that in the first period, TASI has caused DSM and SECTMIND, whereas in the period II, TASI has caused DJI, FTSE, GSPC and IXIC. TASI has only unidirectional causalities. No index has caused TASI in the first period. But, BHSEASI, MSM30 N225 and SECTMIND have caused TASI in the second period.

Most of US indices and the UK index have much bi-directional rather than unidirectional causality. Whereas, most of the GCC indices and the Japanese index have multiple unidirectional causalities rather than bi-directional causalities. TASI and BHSEASI indices have revealed common attributes of having no causalities in the period-I and period-II respectively. FTSE and SECTMIND with nine and eight bidirectional causations have the maximum number of two-way causality in the period-I. In sum, it is revealed that there is change in Granger Causality between TASI and other indices in Period-II, thereby the fifth hypotheses is rejected.

Table 7(A \&B). Pair wise Granger Causality Test summary period (I\&II)

\begin{tabular}{|c|c|c|c|c|c|c|c|c|c|c|c|c|c|c|c|c|c|c|c|c|c|c|c|c|}
\hline \multirow[b]{2}{*}{$(\mathrm{X})$} & \multicolumn{2}{|c|}{ TASI } & \multicolumn{2}{|c|}{ ADSMI } & \multicolumn{2}{|c|}{ BHSEASI } & \multicolumn{2}{|c|}{ DFMGI } & \multicolumn{2}{|c|}{ DJI } & \multicolumn{2}{|c|}{ DSM } & \multicolumn{2}{|c|}{ FTSE } & \multicolumn{2}{|c|}{ GSPC } & \multicolumn{2}{|c|}{ IXIC } & \multicolumn{2}{|c|}{ MSM30 } & \multicolumn{2}{|c|}{$\mathrm{N} 225$} & \multicolumn{2}{|c|}{ SECTMIND } \\
\hline & I & II & I & II & I & II & I & II & I & II & I & II & I & II & I & II & I & II & I & II & I & II & I & II \\
\hline TASI & $\ldots$ & $\ldots$ & $\ldots$ & $\ldots$ & $\ldots$ & $\ldots$ & $\ldots$ & $\cdots$ & $\ldots$ & $\nearrow$ & $\nearrow$ & $\ldots$ & $\ldots$ & $\nearrow$ & $\ldots$ & $\nearrow$ & $\ldots$ & $\nearrow$ & $\ldots$ & $\ldots$ & $\ldots$ & $\ldots$ & $\nearrow$ & $\ldots$ \\
\hline ADSMI & $\ldots$ & $\ldots$ & $\ldots$ & $\ldots$ & $\ldots$ & $\ldots$ & $\ldots$ & $\ldots$ & $\ldots$ & $\nearrow$ & $\nearrow$ & $\ldots$ & $\ldots$ & $\nearrow$ & $\ldots$ & $\nearrow$ & $\ldots$ & $\nearrow$ & $\ldots$ & $\nearrow$ & & $\leftrightarrow$ & $\leftrightarrow$ & $\leftrightarrow$ \\
\hline BHSEASI & $\ldots$ & $\nearrow$ & $\ldots$ & $\nearrow$ & $\ldots$ & $\ldots$ & $\ldots$ & $\nearrow$ & $\ldots$ & $\nearrow$ & $\nearrow$ & $\nearrow$ & $\leftrightarrow$ & $\nearrow$ & $\leftrightarrow$ & $\nearrow$ & $\ldots$ & $\nearrow$ & $\ldots$ & $\nearrow$ & $\leftrightarrow$ & $\nearrow$ & $\leftrightarrow$ & $\ldots$ \\
\hline DFMGI & $\ldots$ & $\ldots$ & $\ldots$ & $\ldots$ & $\ldots$ & $\ldots$ & $\ldots$ & $\ldots$ & $\ldots$ & $\ldots$ & $\nearrow$ & $\leftrightarrow$ & $\leftrightarrow$ & $\leftrightarrow$ & $\ldots$ & $\ldots$ & $\ldots$ & $\nearrow$ & $\ldots$ & $\nearrow$ & $\leftrightarrow$ & $\ldots$ & $\leftrightarrow$ & $\nearrow$ \\
\hline DJI & $\ldots$ & $\ldots$ & $\ldots$ & $\ldots$ & $\nearrow$ & $\ldots$ & $\ldots$ & $\ldots$ & $\ldots$ & $\ldots$ & $\ldots$ & $\ldots$ & $\leftrightarrow$ & & $\ldots$ & $\ldots$ & $\ldots$ & $\ldots$ & $\leftrightarrow$ & $\ldots$ & $\ldots$ & $\ldots$ & $\leftrightarrow$ & $\ldots$ \\
\hline DSM & $\ldots$ & $\ldots$ & $\ldots$ & $\nearrow$ & $\ldots$ & $\ldots$ & $\ldots$ & $\leftrightarrow$ & $\nearrow$ & $\nearrow$ & $\ldots$ & $\ldots$ & $\leftrightarrow$ & $\nearrow$ & $\leftrightarrow$ & $\nearrow$ & $\leftrightarrow$ & $\nearrow$ & $\ldots$ & $\ldots$ & $\ldots$ & $\ldots$ & & $\ldots$ \\
\hline FTSE & $\ldots$ & $\ldots$ & $\nearrow$ & $\ldots$ & $\leftrightarrow$ & $\ldots$ & $\leftrightarrow$ & $\leftrightarrow$ & $\leftrightarrow$ & $\ldots$ & $\leftrightarrow$ & $\ldots$ & $\ldots$ & $\ldots$ & $\leftrightarrow$ & $\ldots$ & $\leftrightarrow$ & $\ldots$ & $\leftrightarrow$ & $\ldots$ & $\leftrightarrow$ & $\ldots$ & $\leftrightarrow$ & $\ldots$ \\
\hline GSPC & $\ldots$ & $\ldots$ & $\ldots$ & $\ldots$ & $\leftrightarrow$ & $\ldots$ & $\ldots$ & $\ldots$ & $\nearrow$ & $\ldots$ & $\leftrightarrow$ & $\ldots$ & $\leftrightarrow$ & $\ldots$ & $\ldots$ & $\ldots$ & $\ldots$ & $\ldots$ & $\leftrightarrow$ & $\ldots$ & $\ldots$ & $\ldots$ & $\leftrightarrow$ & $\ldots$ \\
\hline IXIC & $\ldots$ & $\ldots$ & $\ldots$ & $\ldots$ & $\nearrow$ & $\ldots$ & $\ldots$ & $\ldots$ & $\ldots$ & $\ldots$ & $\leftrightarrow$ & $\ldots$ & $\leftrightarrow$ & $\ldots$ & $\ldots$ & $\ldots$ & $\ldots$ & $\ldots$ & $\leftrightarrow$ & $\ldots$ & $\ldots$ & $\ldots$ & $\leftrightarrow$ & $\ldots$ \\
\hline MSM30 & $\ldots$ & $\nearrow$ & $\nearrow$ & $\ldots$ & $\nearrow$ & $\ldots$ & $\nearrow$ & $\ldots$ & $\leftrightarrow$ & $\ldots$ & $\nearrow$ & $\nearrow$ & $\leftrightarrow$ & $\nearrow$ & $\leftrightarrow$ & $\nearrow$ & $\leftrightarrow$ & $\nearrow$ & $\ldots$ & $\ldots$ & $\leftrightarrow$ & $\nearrow$ & $\leftrightarrow$ & $\ldots$ \\
\hline $\mathrm{N} 225$ & $\ldots$ & $\nearrow$ & $\nearrow$ & $\leftrightarrow$ & $\leftrightarrow$ & $\ldots$ & $\leftrightarrow$ & $\ldots$ & $\nearrow$ & $\ldots$ & $\nearrow$ & & $\leftrightarrow$ & $\ldots$ & $\nearrow$ & $\ldots$ & $\nearrow$ & $\ldots$ & $\leftrightarrow$ & $\ldots$ & $\ldots$ & $\ldots$ & $\nearrow$ & $\ldots$ \\
\hline SECTMIND & $\ldots$ & $\nearrow$ & $\leftrightarrow$ & $\leftrightarrow$ & $\leftrightarrow$ & $\ldots$ & $\leftrightarrow$ & $\ldots$ & $\leftrightarrow$ & $\ldots$ & $\nearrow$ & $\nearrow$ & $\leftrightarrow$ & $\nearrow$ & $\leftrightarrow$ & $\nearrow$ & $\leftrightarrow$ & $\nearrow$ & $\leftrightarrow$ & $\nearrow$ & $\ldots$ & $\ldots$ & $\ldots$ & $\ldots$ \\
\hline
\end{tabular}

Where:

$\mathbf{X}$...Y, means that No causality between $\mathrm{X} \& \mathrm{Y}$.

$\mathbf{X} \nearrow \mathbf{Y}$, means that Unidirectional causality, $\mathrm{X}$ causes $\mathrm{Y}$, but $\mathrm{Y}$ doesn't causes $\mathrm{X}$.

$\mathbf{X} \leftrightarrow \mathbf{Y}$, means that Bi-directional causality, $\mathrm{X}$ causes $\mathrm{Y}$, and $\mathrm{Y}$ causes $\mathrm{X}$. 


\section{Epilogue}

The current study encompasses the linkages among the selected stock market indices through the tools of Correlation, Co-integration and Granger Causality test .From the employment of multiple tools, the following results of hypotheses testing are exhibited. From table 8, it is exhibited that out of five hypotheses taken into consideration, four null hypotheses are rejected. The acceptance of the first hypothesis substantiates that the TASI returns are not normally distributed. The rejection of second hypothesis explains that change in period-wise correlation of TASI with all indices is time variant. The rejection of the third hypothesis evinces that the TASI and other indices in both periods have stationary attributes. The rejection of the fourth hypothesis demonstrates change in co-integration is found between TASI and other indices in Period-II. The rejection of the fifth hypothesis illustrates change in Granger Causality is found between TASI and other indices in Period-II.

Table 8.

\begin{tabular}{|c|c|c|c|}
\hline No & Hypotheses & Accepted & Rejected \\
\hline 1 & The distribution of TASI returns is not normal in the time period (I \& II). & $\sqrt{ }$ & \\
\hline 2 & The period wise correlation of TASI with the Selected Stock Markets Indices is unchanged. & & $\sqrt{ }$ \\
\hline 3 & Existence of Unit Root (non-stationary) in TASI and the Selected Stock Markets indices in the time period (I \& II). & & $\sqrt{ }$ \\
\hline 4 & Co-integration remains unchanged between TASI and the selected stock markets indices in Period-II. & & $\sqrt{ }$ \\
\hline 5 & Granger Causality remains unchanged between TASI and the selected stock markets indices in Period-II. & & $\sqrt{ }$ \\
\hline
\end{tabular}

This study reports interconnections among international bigwig stock indices. Further it is revealed that no stock market has substantially driven other indices. The integration and causation of the stock indices have exhibited the time variant features. In the case of TASI, remarkable traits are revealed in the period-II. The correlation of TASI has increased with seven indices in the period-II. The co-integration of TASI with other indices has increased; likewise TASI has increased one way causality in the period-II. Thus it is cogently deduced that TASI has considerable linkage with international stock indices. The ongoing improvement by the CMA and the legislative reforms shall pull in the international investors' interest in Saudi stock market. Thereby the incessant flow of foreign investment on domestic turf shall assist Tadawul in attaining the status of emerging market.

\section{Acknowledgement}

The Researchers would like to thank the Deanship of Scientific Research at King Saud University, represented by the research center at CBA, for supporting this research financially.

\section{References}

Ahlgren, N., \& Antell, J. (2002). Testing for cointegration between international stock prices. Applied Financial Economics, 12(12), 851-61. http://dx.doi.org/10.1080/09603100110050743

Al-Khazali, O., Darrat, A. F., \& Saad, M. (2006). Intra-regional integration of the GCC stock markets: the role of market liberalization. Applied Financial Economics, 16(17), 1265-1272. http://dx.doi.org/10.1080/09603100500426630

Alkulaib, Y. A., Najand, M., \& Mashayekh, A. (2009). Dynamic linkages among equity markets in the Middle East and North African countries. Journal of Multinational Financial Management, 19(1), 43-53. http://dx.doi.org/10.1016/j.mulfin.2008.03.002

Arouri, M. E. H., \& Nguyen, D. K. (2009). Time-varying characteristics of cross-market linkages with empirical application to Gulf stock markets. Managerial Finance, 36(1), 57-70. http://dx.doi.org/10.1108/03074351011006847

Assaf, A. (2003). Transmission of stock price movements: the case of GCC stock markets. Review of Middle East Economics and Finance, 1(2), 171-189. http://dx.doi.org/10.1080/1475368032000139305

Balli, F., Basher, S. A., \& Jean Louis, R. (2013). Sectoral equity returns and portfolio diversification opportunities across the GCC region. Journal of International Financial Markets, Institutions and Money, 25, 33-48. http://dx.doi.org/10.1016/j.intfin.2013.01.001

Bekaert, G., \& Harvey, C. (1995). Time varying world market integration. Journal of Finance, 50, 403-444. http://dx.doi.org/10.1111/j.1540-6261.1995.tb04790.x 
Bley, J. (2007). How Homogeneous are the Stock Markets of the Middle East and North Africa? Quarterly Journal of Business \& Economics, 46(3).

Bley, J. (2011). Are GCC stock markets predictable? Emerging Markets Review, 12(3), 217-237. http://dx.doi.org/10.1016/j.ememar.2011.03.002

Bodla, B.S., \& Turan, M.S. (2006). Interlinkage dynamics of Asian stock markets, P.U. Management Review, 16(1), 20-34.

Chang, C. P., Chen, P. F., \& Lee, C. C. (2008). Money demand function vs. monetary integration: Revisiting panel cointegration among GCC countries. Mathematics and Computers in Simulation, 79(1), 85-93. http://dx.doi.org/10.1016/j.matcom.2007.10.003

Cheng, A.-R., Jahan-Parvar, M. R., \& Rothman, P. (2010). An empirical investigation of stock market behavior in the Middle East and North Africa. Journal of Empirical Finance, 17(3), 413-427. http://dx.doi.org/10.1016/j.jempfin.2009.11.002

Cheung, Yan-Leung, \& Mak, Sui-choi. (1992). The international transmission of stock market fluctuation between the developed markets and the Asian-Pacific markets. Applied Financial Economics, 2(1), 43-47 http://dx.doi.org/10.1080/758527545

Choudhury, A.R. (1994). Stock Market Interdependencies: Evidence from the Asian NIEs. Journal of Macroeconomics, 16, 629-651. http://dx.doi.org/10.1016/0164-0704(94)90004-3

Dania, A., \& Udemgba, A. B. (2011). Integration Of The Middle East And North African Stock Markets With global Stock Markets. International Journal of the Academic Business World, 5(2).

Darrat, A., K. Elkhal, \& S. Hakim. (2002). On the Integration of Emerging Stock Markets in the Middle Eas. Journal of Economic Development, 25, 61-78.

Driessen, J., \& Laeven, L. (2007). International portfolio diversification benefits: Cross country evidence from a local perspective. Journal of Banking and Finance, 31(6), 1693-1712. http://dx.doi.org/10.1016/j.jbankfin.2006.11.006

Espinoza, R., Prasad, A., \& Williams, O. (2011). Regional financial integration in the GCC. Emerging Markets Review, 12(4), 354-370. http://dx.doi.org/10.1016/j.ememar.2011.04.005

Eun, C.S., \& Shim, S. (1989). International transmission of stock market movements. Journal of Financial and Quantitative Analysis, 24, 241-256. http://dx.doi.org/10.2307/2330774

Forbes, K., \& Rigobon, R. (2002). No contagion, only interdependence: measuring stock markets co-movements. Journal of Finance, 57(5), 2223-2261. http://dx.doi.org/10.1111/0022-1082.00494

Gerrits, R.J., \& Yuce, A. (1999). Short- and long-term links among European and US stock markets. Applied Financial Economics, 9(1), 1-9 http://dx.doi.org/10.1080/096031099332483

Girard, E., \& Ferreira, E. J. (2004). On the Evolution of Inter- and Intraregional Linkages to Middle East and North African Capital Markets. Quarterly Journal of Business \& Economics, 43(1/2), 21-43.

Graham, M., Kiviaho, J., Nikkinen, J., \& Omran, M. (2013). Global and regional co-movement of the MENA stock markets. Journal of Economics and Business, 65, 86-100. http://dx.doi.org/10.1016/j.jeconbus.2012.09.005

Grubel, H. (1968). Internationally diversified portfolios: welfare gains and capital flows. American Economic Review $58,1299-1314$.

Gupta, R., \& Donleavy, G. D. (2009). Benefits of diversifying investments into emerging markets with time-varying correlations: An Australian perspective. Journal of Multinational Financial Management, 19(2), 160-177. http://dx.doi.org/10.1016/j.mulfin.2008.10.001

H. Levy, \& M. Sarnat. (1970). International diversification of investment portfolios. American Economic Review. 60, $668-75$.

Hamori, S., \& Imamura, Y. (2000). International transmission of stock prices among G7 countries: LA-VAR approach. Applied Economics Letters, 7(9), 613-8. http://dx.doi.org/10.1080/13504850050059113

Hoque, H.A.A.B. (2007). Co-movement of Bangladesh stock market with other markets. Managerial Finance, 33(10), 814-6. http://dx.doi.org/10.1108/03074350710779250 
J. Park, \& A. M. Fatemi. (1993). The linkages between the equity markets of the Pacific-Basin countries and those of the US, UK, and Japan: A vector Autoregression analysis. Global Finance Journal, 4(1), 49-64. http://dx.doi.org/10.1016/1044-0283(93)90013-O

Karolyi, G.A., \& Stultz, R.M. (1996). Why do markets move together? An investigation of US and Japan stock return comovement. Journal of Finance, 51, 951-986. http://dx.doi.org/10.1111/j.1540-6261.1996.tb02713.x

Kasa, K. (1992). Common stochastic trends in international stock markets. Journal of Monetary Economics, 29(1), 95-124. http://dx.doi.org/10.1016/0304-3932(92)90025-W

Lagoarde-Segot, T., \& Lucey, B. M. (2007). Capital market integration in the Middle East and North Africa. Emerging Markets Finance and Trade, 43(3), 34-57. http://dx.doi.org/10.2753/REE1540-496X430303

Maghyereh, A. I. (2007). Testing for long-range dependence in stock market returns: a further evidence from MENA emerging stock markets. Applied Financial Economics Letters, 3(6), 365-371. http://dx.doi.org/10.1080/17446540701222417

Masih, R., \& Masih, A.M.M. (1999). Are Asian stock market fluctuations due mainly to intra-regional contagion effects? Evidence based on Asian emerging stock markets. Pacific-Basin Finance Journal, 7, 251-282 http://dx.doi.org/10.1016/S0927-538X(99)00013-X

Neaime, S. (2005). Financial Market Integration and Macroeconomic Volatility in the MENA Region: An Empirical Investigation 1. Review of Middle East Economics and Finance, 3(3), 231-255. http://dx.doi.org/10.1080/14753680500407258

Olusi, O., \& Abdul-Majid, H. (2008). Diversification prospects in Middle East and North Africa (MENA) equity markets: a synthesis and an update. Applied Financial Economics, 18(18), 1451-1463. http://dx.doi.org/10.1080/09603100701720450

Omran, M., \& L. Gunduz. (2001). Stochastic Trends and Stock Prices in Emerging Markets: The Case of Middle East and North Africa Region. Istanbul Stock Exchange Review, 5, 3-16.

Parsva, P., \& Lean, H. H. (2011). The analysis of relationship between stock prices and exchange rates: evidence from six middle eastern financial markets. International Research Journal of Finance and Economics, (66), $1450-2887$.

Paskelian, O. G., Nguyen, V., \& Jones, K. (2013). Did Financial Market Integration Really Happen in MENA Region?-An Analysis. Journal of Economic Cooperation \& Development, 34(1).

Rajiv Menon, N., Subha, M.V., \& Sagaran, S. (2009). Cointegration of Indian stock markets with other leading stock markets. Studies in Economics and Finance, 26(2), 87-94. http://dx.doi.org/10.1108/10867370910963028

Richards, A.J. (1995). Comovements in national stock market returns: evidence of predictability but not cointegration. Journal of Monetary Economics, 36(3), 631-54. http://dx.doi.org/10.1016/0304-3932(95)01225-7

Siddiqui, S. (2009). Stock Markets Integration: Examining Linkages between Selected World Markets. Vision: The Journal of Business Perspective, 13(1), 19-30. http://dx.doi.org/10.1177/097226290901300103

Taylor, M.P., \& Tonks, I. (1989). The internationalization of stock markets and the abolition of U.K. xchange controls. Review of Economics and Statistics, 71, 332-336. http://dx.doi.org/10.2307/1926980

Yu, J.-S., \& Hassan, M. K. (2008). Global and regional integration of the Middle East and North African (MENA) stock markets. The Quarterly Review of Economics and Finance, 48(3), $482-504$. http://dx.doi.org/10.1016/j.qref.2006.06.003 